\title{
THE DESCRIPTION OF PRINCE TIMUR'S LAMENESS IN LIGHT OF MANUSCRIPTS ILLUSTRATIONS AND THEIR RECORDED DESCRIPTIONS IN THE HISTORICAL SOURCES
}

\author{
Sayed, R. \\ Islamic Archaeology dept., Faculty of Archaeology, Fayoum univ., Fayoum, Egypt. \\ E-mail: ras01@fayoum.edu.eg
}

\begin{abstract}
Manuscripts paintings are mirrors of the age as they document everyday life. They are considered as illustrating documents that can be utilized in determining people's descriptions and attributes. Therefore, the current study used them to match the description of Timur's lameness in his right foot with the descriptions in the historical resources. The right foot of prince Timur appeared extended forward and was put on a foot stool in front of the throne, while he could not sit cross-legged (called in Arabic Altarbiaa), and could not sat on hips (called in Arabic Altawarok). These sittings were common for sultans and princes. Manuscripts paintings appear here with very realistic drawing of the phenomenon of lameness. However, facial features differed in some paintings. For example, the painting drawn by Behzad was very realistic although it was painted in a later period of the reign of Timur. Thus, Behzad might relied on historical resources. It was observed that the sittings, illustrating this phenomenon (i.e. lameness), for prince Timur were for those who sat on the throne. The study utilized paintings, which manifested lameness in manuscripts, such as Zafarnama (Book of Victory) and the descriptions of that phenomenon in the historical resources, e.g. Ibn Arabshah (Ajaib Almaqdoor - in Arabic), Ibn Khaldun (Tarikh Ibn Khaldun - in Arabic), and other historical sources.
\end{abstract}

Keywords: Manuscript-Timur - Lameness- Ibn Khaldun- Historical Sources.

\section{Introduction}

Miniatures are often looked upon as mirrors of the age in terms of documenting everyday life, and architecture. They can be relied upon in determining people's descriptions and physical features. Therefore, the current study utilized them to match their depictions of prince Timur Kourkan in miniatures with the historical sources, focusing on the lameness of his right foot. "Ruy Clavijo", the Spanish ambassador, claimed that he and the staff of the embassy were received in Samarkand in 1405 AD in tent-like suites amid gardens. They were internally covered with embroidered silk with eagles and vultures, either flying or ready to pounce on their prey. According to Babur, the grandson of Timur, some paintings in Samarkand's restrooms depicted his victories in India. Unfortunately, they totally disappeared [1]. The current study utilized the paintings that depicted "lameness" in manuscripts e.g. Zafar Nama. It also made use of the historical sources, including Ibn-Arbashah's, "Aja'ib al-Maqdur fi Nawa'ib alTimur (The wonders of destiny of the calamities of Timur), and Ibn-Khaldun's, "Ibn-Khaldun's history", who was the envoy of Al-Nasir Faraj Ibn-Barkok to Timur in 803 A.H. 


\section{Lameness From a Linguistic Perspective}

According to Al-Razi, one went lame if he/she was injured in his leg and walked as the lame. In Arabic, it is "araj (went lame), arjan (lame), Aarjah Allah (God made him lame), and ma ashada arajahu (what severe lameness he has).
In addition, "Arjan" with two fathas is used to describe the lame walk [2]. According to Almoajam alwaseet, "araja alshaee" means something. If somebody is injured in his leg so he lamed "araja" [3].

\section{Timur's Biography and Characteristics 3.1. Timur's biography by Ibn Arbashah}

His name was Timur, Tumur, or Tamr Link. In Turkish, he was known as "Al-Hadeed ben Trgay bin Obgay". He was born in "Khawaja Ilgar" village in $\mathrm{Kish}^{(\mathrm{a})}$ [4]; a city of Transoxiana ${ }^{(\mathrm{b})}$ [4]. It was a third of a month away from Samarkand. It was claimed that when he was born, he was seen as if something similar to the helmet that appeared in the open air. Then, he fell to the courtyard. If he touched the ground, he spread, and blew like embers and sparks. It was also claimed that when he was born, his hands were dyed blood. People

\subsection{Timur's biography by Ibn Taghry Barady}

He was called Tamr and Timur. He is ibn Etmash Guenlg ibn Sniba ibn TarmTara ibn Taghril ibn Qalij ibn Sanghur ibn Kanjak ibn Taghrasbuqa ibn Altakhan $^{(c)}$ [6-9]. He was a tyrant. In Arabic, his name means defeater of kings $[10,11]$. He was born in 728 A.H. in Khwaja Apgar village [5] in Kish. It was a city of Transoxiana and was one day away from Samarkand. It was said that when he was born, he was he was seen as something similar to the helmet inquired about his conditions and checked for the interpretation of the priests. While some priests argued that he would be a policeman, others said he would be a thief, a third group said that he would be a forger and murder, and fourth group argued that he would be an executioner and lasher. He and his father had neither mind nor religion. It was said that they were of wandering travellers and unemployed bastards. They lived in Transoxiana. His father was a very poor shoemaker, and he was an extremely strong young man [5].

that appeared in the open air. Then, he fell to the courtyard. His hands were also dyed blood. Therefore, he was thought to be shedder of blood ${ }^{(\mathrm{d})}[12,13]$. It was claimed that his father was a shoemaker but others claimed that he was a prince with Sultan Hussein of Balkh ${ }^{(\mathrm{e})}$ [4]. His mother was a descendant of Genghis Khan. It was also reported that Sultan Hussein had four ministers and Timur was one of them [10].

\subsection{Timur's characteristics reported by Ibn Arbasha}

Ibn Arabshaha reported that Timur was a strong and tough young man. One night, he stole some sheep, but the shepherd hit him in the shoulder with an arrow and another in the thigh and so caused much pain. Despite his poverty and malignance, he had a desire to corruption. In addition, he sought to be a king. Thus, his companions accused him of He sang: If destiny helps, the strict goes with the disabled [5]. madness and. They even laughed at him.

\subsection{Timur's characteristics as reported by some Arab historians}

Ibn Taghri Baradi stated "... and he was originally from Berlas tribe. At first, he was known to be a criminal. One night, he stole some sheep, but the 
shepherd was aware. Thus, he hit him in the shoulder with an arrow and another in the thigh, causing him lameness. Therefore, he was called Temūr(-i) Lang; Timur the Lame. When recovered, he became a criminal with a gang of forty men. At that time, he used to tell that he would become a king and kill other kings. Some of them laughed at him, while others believed because of his firmness and courage [10]. He continued describing Timur's physical features, claiming that "he was tall, with a great front, great appearance, and great strength. He was white color tinged with reddish with broad shoulders, thick fingers, thick elbows, fitness, long beard, and lameness in the right leg. In addition, he was not afraid of death $^{(\mathrm{f})}[10,13,14]$.

\subsection{Timur's characteristics as reported by Ibn-Khaldun ${ }^{(\mathrm{g})}$}

$\mathrm{He}$ reported that this King, named Tamr, was one of the leader kings and was a tyrant. People attributed knowledge to him, and others attributed the belief of rejecting faith as they thought that he preferred the Family of Prophet Muhammad and others thought that he was a magician. However, all of these were no more than claims $[15,16]$. He had much wit and intelligence. He sought research and was wandering a lot including what he knew and what he did not. He was aged sixty to seventy. His right knee was idle due to an arrow that injured him in the raid on days of his youth. Therefore, he pulled it in a nearby walk, and men carried him on hands for longer ones. It was his destiny because Allah gives His sovereignty to whom he wills [15].

\section{A Brief Overview of Painting in the Timurid Era}

The era of Timor and his successors was one of the most flourishing eras of painting in Iran, where there were many institutes for writing arts to create manuscripts decorated with colorful paintings and to train artists to create such art works. There was an integrated team to be trained, including calligraphers, statue makers, those working on gold, bookbinders...etc. Many of famous artists and statue makers graduated from these institutes. For example, Behzad was working in writing arts in Herat in the late Timurid era. In the Timurid era, many painting centers remarkably flourished across Iran, in Shiraz, Tabriz, Samarkand, the capital of the first Timurid State and then in the second capital which lasted until the end of the Timurid era in Herat, and Bukhara. They all produced decorated manuscripts [17].

\section{Models of the Manuscripts Under the Study \\ 5.1. Prince Timur's victory and his accession to power at Balkh ${ }^{(\mathrm{h})}$}

The $1^{\text {st }}$ one, fig. $(1-\mathrm{a}, \mathrm{b}, \mathrm{c})^{(\mathrm{i})}$, it named "Zafar Nama" by Sharaf al-dein Al-yazdi [18], and it placed in John Work Garrett collection [19]. Its description shows prince Timur sitting on the throne in quarter - triple position of forward. He was wearing a green rope and a crown with a feather on its top. He also had a sharpened beard. What matters here is his sitting on the throne; his left leg was in a cross-legged (Altarbiaa) position, while he put the right leg on a foot stool in front of the throne as he was not able to flex it due to the disability. In my opinion, this painting was created by Behzad because it was modeled after his style ${ }^{(J)}[18,17]$. 

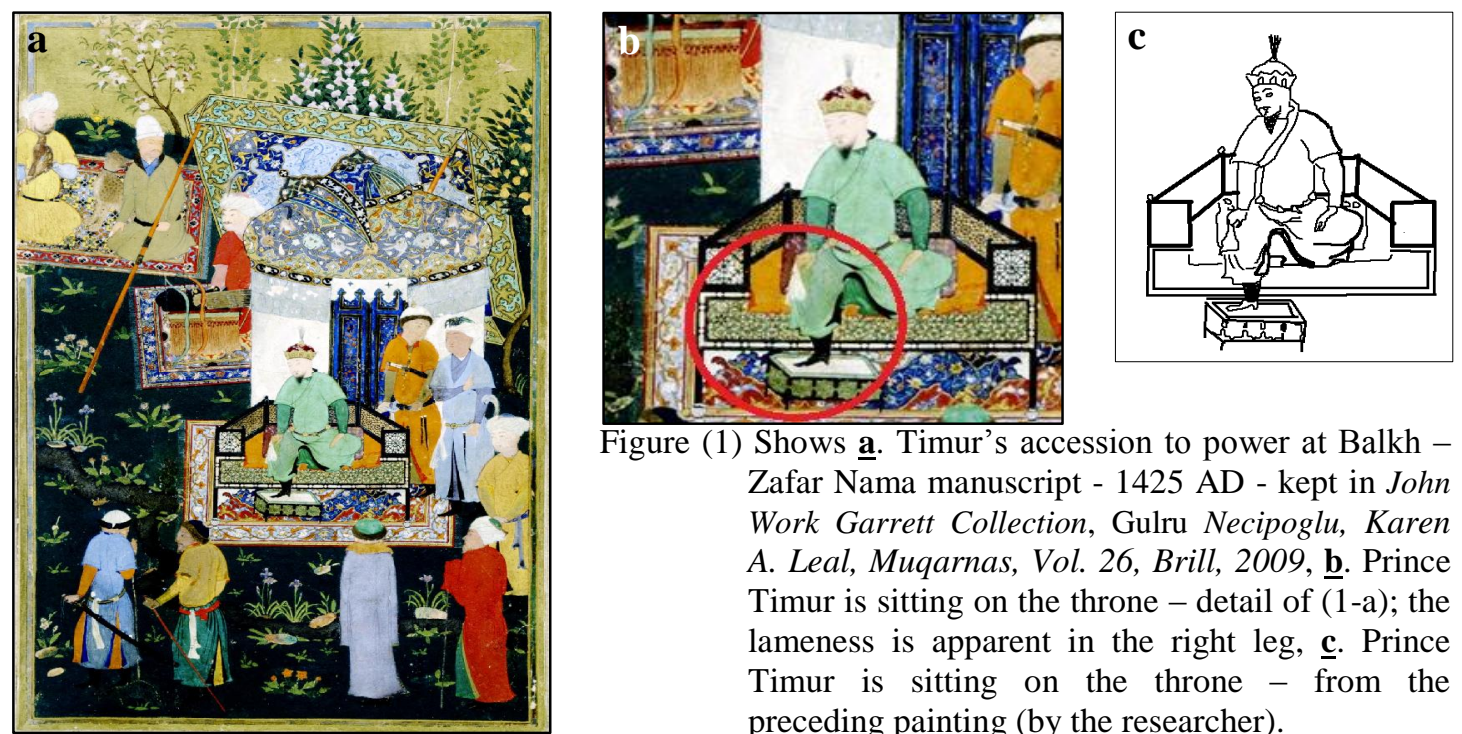

Figure (1) Shows a. Timur's accession to power at Balkh Zafar Nama manuscript - 1425 AD - kept in John Work Garrett Collection, Gulru Necipoglu, Karen A. Leal, Muqarnas, Vol. 26, Brill, 2009, ‥ Prince Timur is sitting on the throne - detail of (1-a); the lameness is apparent in the right leg, c. Prince Timur is sitting on the throne - from the preceding painting (by the researcher).

\subsection{A painting of the mirth court of prince Timur}

The $2^{\text {nd }}$ manuscript, fig. $(2-a, b, c)$ was named "Divan of Shah Qasim Anvar" by Mu'inaddin Ali of Tabriz (1356-1433 AD). It dates back to 1489 A.D during the Timurid era" and it measures $30 \times 20$ $\mathrm{cm}$. It a painting that shows prince Timur sitting on the throne in quarter - triple position from the front part. He was wearing a green caftan with tight sleeves, a red jubbah, and a crown with a feather on the top. He stretched his right hand forward towards the person who is sitting on his hips (Altawarok) to get a tumbler. What matters here is prince Timur's sitting and bending his left leg in a crosslegged position, whereas his right leg was extended down because he can't flex his knee as a result of the disability.
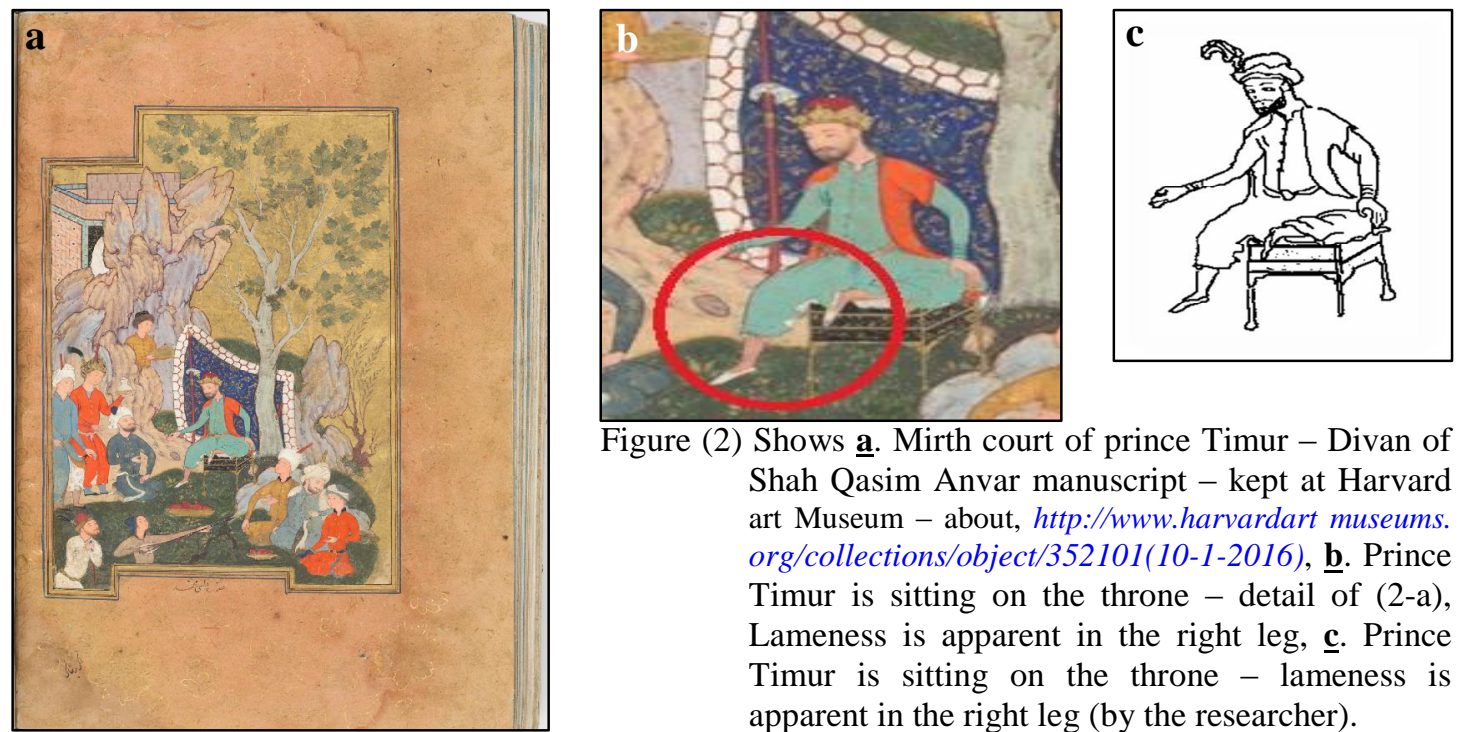

Figure (2) Shows $\underline{\text { a. }}$. Mirth court of prince Timur - Divan of Shah Qasim Anvar manuscript - kept at Harvard art Museum - about, http://www.harvardart museums. org/collections/object/352101(10-1-2016), b. Prince Timur is sitting on the throne - detail of (2-a), Lameness is apparent in the right leg, c. Prince Timur is sitting on the throne - lameness is apparent in the right leg (by the researcher).

\subsection{A painting of prince Timur celebrating the Eid}

The $3^{\text {rd }}$ one, fig. ( $\left.3-\mathrm{a}, \mathrm{b}, \mathrm{c}\right)$ is

"Timur Nama Hatifi" manuscript that kept at Harvard Art Museum under the number 1957.140.34, it measures $20.13 \times 14.24$ $\mathrm{cm}$. The painting shows prince Timur's celebration of the Eid in Samarkand. He was sitting on the throne. His body and face were painted in a front view in a quarter triple position. He was wearing a crown, a red caftan with tight sleeves, and a green jubbah with an apparently fur edge. It was decorated with floral ornaments. What matters here is prince Timur's sitting with his left leg in a cross-legged position while the right leg that with lameness appeared unstable. It was put on a foot 
stool at the foot of the throne. He leant his right hand on his knee that had

lameness. He put $\mathrm{Al}$ heasa ${ }^{(\mathrm{k})}$ around his waist [20-24].
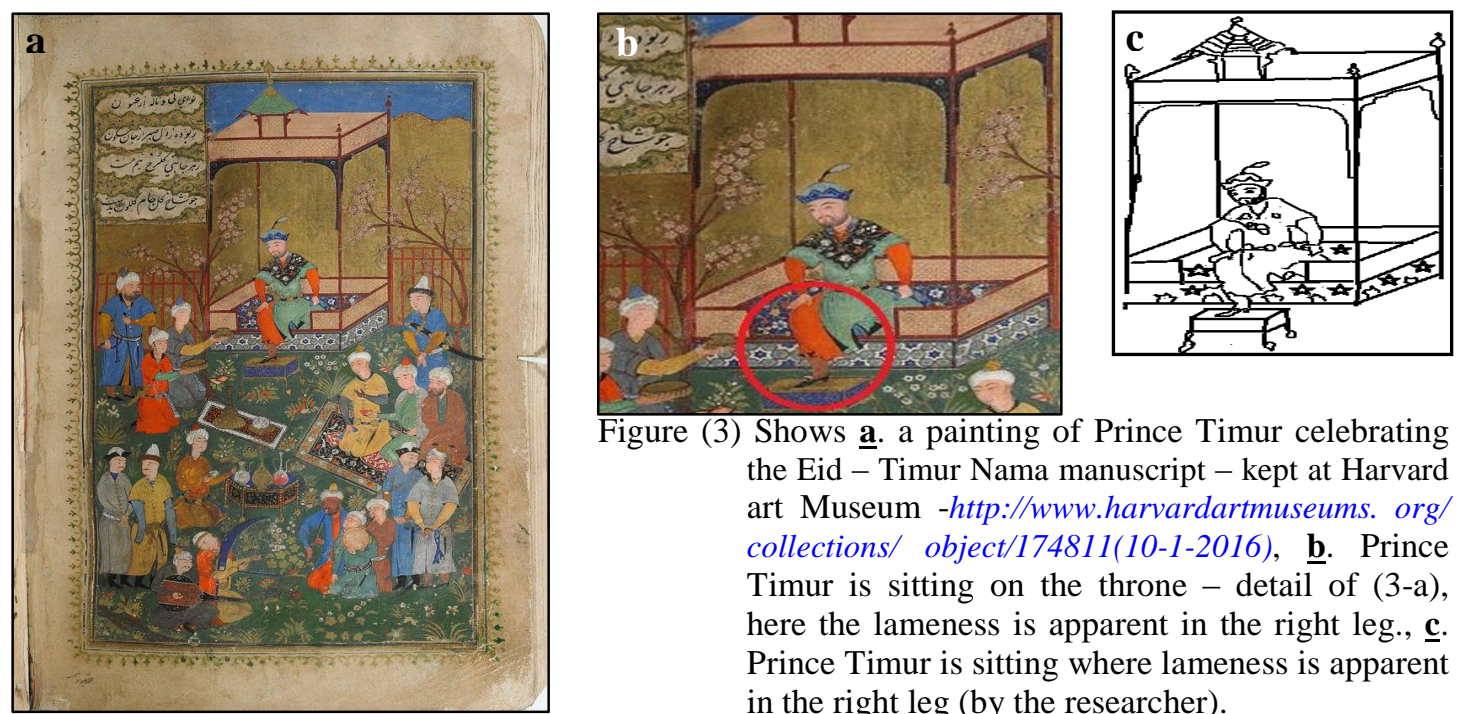

Figure (3) Shows $\underline{\mathbf{a}}$. a painting of Prince Timur celebrating the Eid - Timur Nama manuscript - kept at Harvard art Museum -http://www.harvardartmuseums. org/ collections/ object/174811(10-1-2016), ㅁ. Prince Timur is sitting on the throne - detail of (3-a), here the lameness is apparent in the right leg., $\underline{\mathbf{c}}$. Prince Timur is sitting where lameness is apparent in the right leg (by the researcher).

\subsection{A painting of prince Timur celebrating a victory ${ }^{(1)}$ in Samarkand in the open air}

In this painting, fig. (4-a, b, c), Prince Timur appears in the middle of the painting in a front view of the quarter-triple position. He was wearing a brown robe with tight sleeves and a green jubbah with a decorated edge. The sleeves reached the elbow. He was wearing a bonnet $^{(\mathrm{m})}$ [25] with a feather

on its top that draped over to the back. He was holding a cup in his left hand. He appeared in a sharpened trimmed beard. What matters here is prince Timur's sitting; his left leg was in a crosslegged position, while the right leg with lameness was stretched. Musicians, retainers, and servants were all around him.
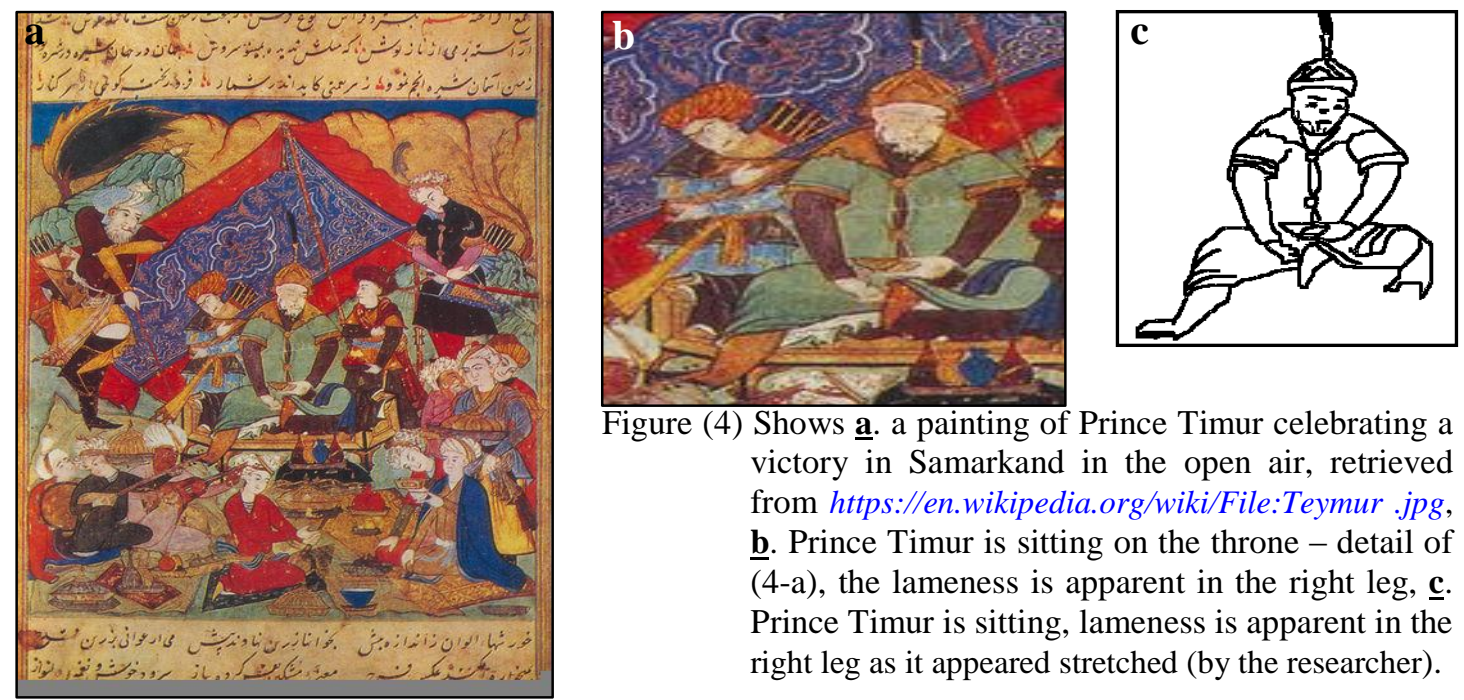

Figure (4) Shows $\underline{\text { a. }}$ a painting of Prince Timur celebrating a victory in Samarkand in the open air, retrieved from https://en.wikipedia.org/wiki/File:Teymur .jpg, b. Prince Timur is sitting on the throne - detail of (4-a), the lameness is apparent in the right leg, $\underline{\mathbf{c}}$. Prince Timur is sitting, lameness is apparent in the right leg as it appeared stretched (by the researcher).

\subsection{Prince Timur sitting on the throne - Tashkent Museum}

As it could be shown in fig. (5$\mathrm{a}, \mathrm{b})$, prince Timur was sitting on the throne and the retinue around him. His body and face were painted in quarter triple position from the front. He was wearing a green caftan with tight sleeves, jubbah with geometric motifs in the form of stars, crown with a feather on the top, and Al- Heasa around his waist. $\mathrm{He}$ was sitting on the throne with his left leg in a cross-legged position, whereas the right leg with lameness was put on a foot stool in front of the throne. He was leaning his right hand on the right leg. 

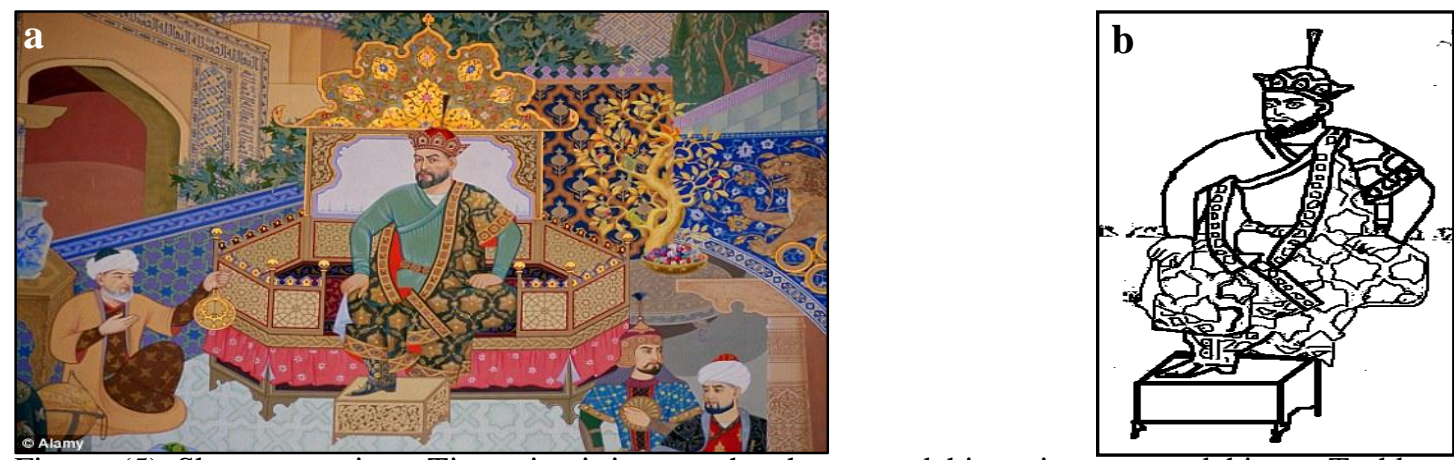

Figure (5) Shows a. prince Timur is sitting on the throne and his retinue around him - Tashkent Museum- about http://www.advantour.com/uzbekistan/tashkent/amir-temur-museum.htm (10-1-2016), b. Prince Timur is sitting on the throne - lameness is apparent in the right leg and he put it on a foot stool (by the researcher).

\section{The Comparative Study}

In terms of matching prince Timur sittings on the throne in the preceding paintings with those, fig. (6-a) [26], it is observed that there was an obvious error in the painting. His right leg with lameness was bent and the left leg was stretched on the foot stool. This contradicted what was reported in the paintings and the historical sources under study. O'kane argued that this painting might be created by AqaMirak [27]. It seemed that Mirak didn't realize this error in his painting. Thus, it was not real enough, unlike the painting of Behzad, which was realistically, fig. (1$a, b)$. Another error of Timur celebrates his conquest of Delhi, fig. (6-b) (for unknown painter) in a painting from Zafar Nama; Timur appeared sitting crosslegged on a carpet and holding a cup in a celebration. The painting wasn't realistic, as he could not sit in that position. I think that the painter wanted to show Timur at best; free of defects. By comparing Prince Timur's sitting on the throne with those of other sultans and princes, there was a variation. Some sittings were in a crosslegged position. For example, a painting illustrated Genghis Khan on the throne and his retinue was around him (from the manuscript of Jami' al-tavarikh by Rashidal-Din, Timurid Era, 1425 AD). He was sitting cross-legged on the throne, fig. (6-c). He took the quarter-triple position from the front with both legs bent. By comparing this sitting with prince Timur's, they kept the same sitting except for prince Timur's right leg. Another example is the coronation of Luhrasp in $1439 \mathrm{AD}$ (from Shahnama of Baysunghur manuscript). He was sitting altaribiaa and his body and face were painted in quartertriple position from the front, fig. (6-d). By comparing this painting with those of prince Timur, that he also took crosslegged position except for the leg that had lameness that was stretched. From the same manuscript, a painting illustrated Kisra listening to Buzurjmihr who was explaining the chess game, fig. (6-e). He took a cross-legged position on the throne with both legs bent. He took the quartertriple position of forward. He was rising his right hand a little up in an attempt of the painter to express a movement. If compared to prince Timur's sitting, they took the same position except for the right leg with lameness. So, it appeared stretched. In the painting of the king and the beggar manuscript of Mantiq al-Tayr by Farid al-Din 'Attar), fig. (6-f), the king's sitting on the throne is different. The king appeared sitting on the hips (Altawarok) and both of his knees were bent to the back. His body and face were painted in a quarter- triple position (taking a front view). There was an obvious difference between this sitting and prince Timur's sitting on the throne. In the painting of the ceremony of pres-enting the manuscript to Sultan Mirza Barlas, fig. (6-g), he appeared sitting cross- legged on the throne. By comparing it with prince Timur's paintings, the same sitting was taken except for prince Timur's right leg. 

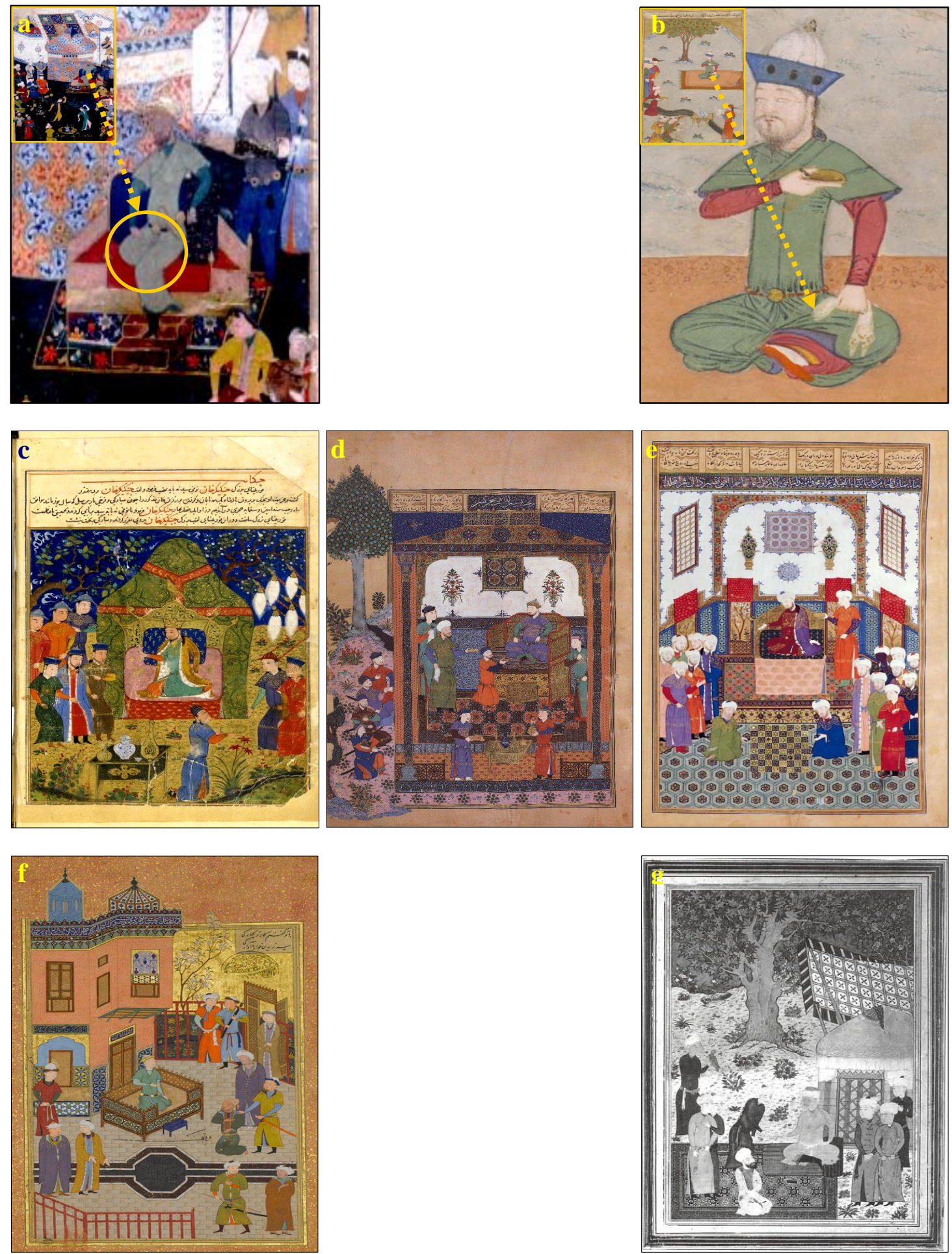

Figure (6) Shows a. the Marriage of Timur and Dilshad Agha, Zafar nama (Book of Vic-tory) of Sharaf alDin Ali Yazdi, copied by Hamd Allah ibn. Murshid al-Katib, 1486 AD (891 AH.), Iran, Museum of Turkish and Islamic Art, Istanbul [27], b. Timur celebrates his victory in Delhi, Zafar Nama, 1436, Timurid period, http://www.harvardartmuseums.org/art/215330 (12-5-2017), c. Genghis Khan is sitting on the throne and the retinue around him, Jami' al-tavarikh manuscript, 1425 AD, by Okasha, Persian and Turkish painting, p, 105, d. the coronation of Luhrasp, Shahnama Baysunghur 1439 AD [18], e. kisra is liste-ning to Buzurjmihr who is explaining the chess gameGulstan Palace Library in Tehran, Sha-hnama of Ba-ysunghur 1439 AD [18], f. the king and the beggar - Mantiq al-Tayr manuscript - by Farid al-Din 'Attar by Behzad-Herat 1487 AD, https://www.pinterest.com/pin/ 548805904569476455/(12-42016) Baysunghur 1439 AD [18], g. Ceremony of presenting the manus-cript to Sultan Mirza Barlas - Khamsah of Nizami manuscript - Herat - 1495 AD - The British Museum [18] 


\section{Conclusion}

Through the previous study, some essential remarks could be concluded: (1) Miniatures are pictorial historical documents for this period of history in general, and prince Timur, in particular. They can be used to recognize the social and cultural aspects. (2) The miniatures, under study, helped match the physical attributes of prince Timur, especially lameness. (3) The historical resources differed on the character and attributes of prince Timur. Ibn greatly hated Timur (probably because he waged wars in the Levant). Ibn Taghry Bardy (Al- Manhl Al- Safi) at the beginning can't agree more with Ibn Arabshah. Then, he praised him mentioning his morals and physical features. (4) Prince Timur's took cross-legged position, while the right leg was stretched because it had the lameness and he was not able to flex it, so he put it on foot stool in front of the throne. (5) The historical resources differed about the reasons of lameness. Ibn Arabshah stated that Timur was stealing a goat, so the sheep owner hit him with an arrow in his hand and another in his leg by which he had lameness for the rest of his life. It could be concluded that he was a thief. Ibn Taghry Bardy and Al-Sakhawi reported that Timur was hand paralyzed and right leg crippled. Actually, I did not see the handicap of the hand in any of the paintings I studied. It appeared holding cups. (6) Ibn Khaldun's story about Timur's lameness was the nearest to the reality as he stayed with him for more than thirty days. He reported that Timur was infected with lameness because he was struck by an arrow during one of his raids. (7) The miniatures utilized were painted realistically to some extent, especially prince Timur's sitting and appearance. They had the characteristics of Muzaffarid and Timurid Schools, especially in their movements.

\section{Endnotes}

(a) Kish is a village that is three leagues from Gorgan on a mountain. Abu Zarah Mohammed bin Ahmed bin Youssef bin Mohammed bin Junaid Kishi Jerjani" was one of its famous people, He narrated on Abu Naim Abdul Malik bin Mohammed bin Uday, Macki ibn Abadan, Abdul Rahman bin Abi Hatim, and others. Abou El Fadl Maqdisi said that Kishi was from a village in Transoxiana. In addition, Abdulrahman bin Humaid Al Kishi was from this village. Furthermore, Ibn Makola said that the great relater $\mathrm{Abu}$ Muslim Ibrahim bin Abdullah bin Muslim Elbasry Al Kishi and his son Muhammad ibn Abi Muslim Al Kishi was from there. He claimed that he heard Abu al-Qasim alShirazi saying that the title Albasry qas used because he built a house in Basra. He also said 'bring Alkj'. Others mentioned Bilkjy said Kishi. Alkj with jeem in Persian means plaster. Abu Musa Al-Hafiz Asbahani argued that all what he said were claims; if what he said was right, he would say Alkjy with jeem. I think, he continued, that he was from a place in Khuzestan, known as zeer
Kaj. Abu Musa reported that Kish is a village in Isfahan. A group of scholars was there.

(b) Transoxiana was used to refer to an area beyond Amu Darya river. To the east, it was known as Hephthalites. In Islam, it was called Mā wará' alNahr. In the west, there were he Khorasan and Xorazm region that was an independent province. Transoxiana was a fertile region where a generous nation lived although it was strong and fierce. It was even more fertile than any other country across the world. There was not even a place on earth that pass draught but before Transoxiana. When they faced a problem in food supplies, what they had was enough not seek the help of any other country. It was populated and fully constructed. Its water was sweet and was everywhere. They also had enough livestock as well as donkeys, camels, and mules. Their sheep were brought from Western Turkmenistan and other countries. Their clothes were made of cotton, silk, and wool. They also exported textiles.

(c) There is disagreement among historians about the extension of Timor 
series. Historians who lived in the era of Timur and wrote his biography did not mention its origin and nothing whatsoever, but little information were received about the lineage series on a stone inscription written on his tombstone in Samarkand. It came in this engraving, who came in Arabic, which reported Baluchi and saying, "this is the tomb of the greatest sultan Khacan Noble Prince of Timur Korkan son of prince Trgay, the son of Prince kicked the son of Prince Ailinkar, the son of Prince Eagle, Ben Qrajar Noyan, the son of Prince Sugu Jegn, the son of Prince Ibrid Magy Parola son Prince Qjulay bin Tomnay Khan, the son of Prince Baisunghur bin Gedo Khan bin Amir bin Tutumn the son of Prince Poka". The Persian poet Abdullah Hatifi, who died in 957 AH / 1521 A.D pointed out a relationship between Qrajar and Genghis Khan, saying: "Genghis khan and Qrajar are cousins... they are also in opening countries", and historians who used to refer to Timur or Prince Sultan or King, and the Europeans referred it as it Tame-rlane".

(d) Its translation also came in Qalqashandi who mentioned it saying "Tomr ", the name which was signed with, meaning in Turkish "iron", and " Link" means " Lame " Oqsq" and Oqsq have meaning of lame.

(e) Balkh was a famous city in Khorasan. According to the epic book by Ptolemy, it was in the fifth province. It was one of the greatest, most beautiful, and richest cities in Khorasan. Its crops were exported to other areas of Khorasan and Khorezm. It was claimed that it was first established by Hrasef King, whereas others claimed that it was built by Alexander (and was called Alexandria in ancient times). It was twelve leagues from Qrphid and was 10 leagues from Amu Darya river that was named after it. In the reign of Othman bin Affan may Allah be pleased with him, it was conquered by Ahnaf bin Qais who was commissioned by Abdullah bin Amer bin Craze.

(f) His attributes: He hated banter and lying. He had little tendency to have fun although he liked it. His ring was engraved "Rusty Rusty" which means "If you tell the truth, you survive". It was not also allowed to have obscene speech, bloodshed, captivity, plunder, nor raid in his council. He was a giver and obeyed, brave, and intrepid. He also liked the brave and offered them all good things. Additionally, he had a fantastic acumen and great noticeable respect from his flock. He had firm will and understanding and was alert. $\mathrm{He}$ was said to be the ruler of the seven regions, ember of water and mud, and overcomer of kings and sultans. $\mathrm{He}$ was fond of listening to the history and stories of the prophets, peace be upon them, that he was well aware of them that he responded to a reciter if he mistaken. He was fond of science and scholars that he drawn the masters of science and craftsmen. His prestige was of wisdom and dignity. He also had debates with scholars. On the contrary, he hated poets and stooges. He believed in the sayings of doctors and astrologers. However, he was illiterate and knew nothing of Arabic. He was well-aware of Turkish, Persian, and Mughal.

(g) The reasoning for Ibn Khaldun's narration is really important as he was the ambassador of sultan Alnaser Abu El Saa'dat Farj ibn Barquq to the prince Timur 803A.H. He stayed in the court of Timur for more than a month.

(h) Prince Timur was crowned over Transoxiana in 771 A.H /1369 A.D. When he arrived, prince Hussein moved forward to fight. However, he got defeated and returned to Balkh and fenced in the castle after a severe murder by Timur and his strong army. Then, they made agre-ements 
with Timur to leave for Makkah. Afraid of deception, Hussein went out of the castle and was hidden in Balkh's minaret. However, the army of Timur found him and brou-ght him in front of their commander, where he and Khan Cable Shah were sentenced to death for his collabor-ation. He ordered to completely destroy Balkh castle and its settlements. After achieving victory, he was crowned in Ramadan of 771 A.H./ 1370 A.D.

(i) Zafr Nama "i.e. life of Timur" is the most famous masterpiece in the times of Prince Ibrahim Sultan. Sharf el Dein Ali el Yazdi completed it in 1425 A.D.

(j) Kamaluddin Behzad was born in the middle of the $9^{\text {th }}$ Hijri/ $15^{\text {th }}$ (A.D.) century. During the rule of Sultan Hussein Mirza Baiqra (1416-1506 AD). A new artistic era emerged in the city of Herat. The Sultan and his minister the poet "Mir Ali Sher Navoi" encouraged artistic renaissance and pledged to care and honor. At that time, Behzad worked in "the kitab khana" Institute. His artistic styles could be traced from 1410 AD. He had many followers and gained fame until had an artistic school. They followed in his footsteps, such as "Qasim Ali", "Sheikh Zadah", "Mahmoud Mazhb", "Aqamirk", and "Sultan Mohammed". When Shah Ismail came to power in 1502 A.D., he summoned Behzad to his capital Tabriz, where he paid him much care and good respect. It was said that when Shah Ismail came out to fight the Turk 1514A.D., he concealed Behzad and the calligrapher Shah Mohammad Alnisabure in a cave, protecting their lives. When he returned, he first asked about the artist Behzad and his colleague. It was reported that the historian Khwandemar that Behzad surpassed all his contemporaries. It was claimed that "one hair from his brush was, thanks to his genius, able to turn concrete objects alive". When Shah Ismail died, Behzad worked for his son Tahmasp (1524-1576 A.D.) that he taught him painting. His artistic style was characterized with obvious features, including simple performance and reality in the works and movements. He tried to distinguish them, especially those who have beards. He tried to express their feelings, emotions, and integration in his woks. Concerning colors, he mastered using suitable and different degrees of colors in harmony. He also added colors of his own to the list of colors used in painting inside the Timurid school. Furthermore, he added the sense of life and movement to the paintings of animals, trees, especially when he painted a picture of a horse eating grass among rock hills. He was able to create pictures like a panel of mosaic comprising parts of different views that may combine landscape and architectural background, covered with fine decorative elements.

(k) Alhayash (cinch) in the belt or it's an animal belt. It was used for everything tightening the human waist. It was used in the military in the Ayyubid and Mamluk periods. It was made either of gold or silver plated with gold. It was worn by the princes when the king honored them. It varied according to rank; some of them had gold-studded stones but others were not. Dozy believed that Alhayash was made of gold or silver but not of skin or cloth fabrics. According to Abdel Jawad, Al-Maqrizi said that Egypt had a market called Alhawwaeseen where Alhayash were sold. It was reported that it was used for women, e.g. in One Thousand and One Arabian Nights.

(1) It was taken from Zafar Nama manuscript by Sharaf al-Din Yazdi.

(m) Calantica (bonnet) it is composed of kula (head) and bush (cover). It is better to say that it is originally French from Calotte. In Arabic, it is a bonnet with various forms and colors. 


\section{References}

[1] Okasha, T., (2001). Mawssoat altasweer Al-Islami, Lebanon Library, Beirut.

[2] Al-Razi, M., (1911). Mukhtar Alsahhah, $1^{\text {st }}$ ed., Alkolea Press, Cairo.

[3] Academy of Arabic Language, (1994). Elmoajam alwajeez, Ministry of Education Press, Egypt.

[4] Hamwi, Y., (1977). Mu'jam el-boldan, Vol 4, Dar Sader, Beirut.

[5] Ibn Arabshah, Sh., (2005) Aja'ib almaqdur fi nawa'ib Timur, Al-Risala Lil Nashr, Damascus.

[6] Shahab, M., (1981). Timurlank, asrooh, hayatooh wa a'malooh, Ph.D., dept., College of Arts and Humanities, Saint Joseph Univ., Beirut.

[7] Nasser, H., (2009). Timurlank wa shakhsitoh al-siasia wa al-askaria, Ph.D., History dept., Faculty of Arts and Humanities, Damascus Univ., Damascus.

[8] Partold, F., (1996). Tarikh Al-Turk fi Asia Al-wostaa, General Egyptian Book Authority, Cairo.

[9] Clavijo, G., (2006). Embassy to Tamerlane (1403-1406), Taylor \& Francis Group, UK.

[10] Abu El Mahasen, Y., (1986). AlManhil El Safi wi elmustawfi b'ad elwafi, Vol. 4, General Egyptian Book Authority, Cairo.

[11] Iqbal, A. (1990). Tarikh Iran ba'd al-islam monz bedait al-dawlaa AlTahriaa hatta nihayt Al-dawlaa AlQajaria (820-1925, Dar Al-thakafa Lel-nasher Wa El-tawziee, Cairo.

[12] Qalqashandi, A., (1945). Subh alasha, Vol. 7, Al- Haiaa Al-Amma Lel Matabie Al-America, Cairo.

[13] Al-Sakhawy, S., (1960). Al-dwaa al-lamie li ahl al-qarn al-tasie, Vol. 3, Dar-Algeel, Beirut.

[14] Bukhari, M., (2007). El-taj el-mekalel mn gwaher ma'ther el turaz el awl wi el akher, Ministry of Awqaf and Islamic Affairs, Qatar.

[15] Ibn Khaldun, A., (2000). Tarikh Ibn Khaldun: Diwan el mubtada' wi el khaber fi zikr Al-Arab wa Al-Barbar wa mn khalathom mn zawee Al-soultan Al-akbar, Vol 7, Dar Al-Fikr, Beirut.

[16] Ibn Khaldun, A., (1979). Al-tareef be Ibn Khaldun wa rehalatih Sharkan wa Gharban, Dar Lebanese writer for Printing and Publishing, Beirut.

[17] Mahmoud, A., (2000). Al-tasweer Al-Islami, nash'toh, mawkif al-islam minhoo, wa osoloh, wa madarisoh, Egyptian Lebanese House, Cairo.

[18] Okasha, T., (1983). Al-tasweer AlFarsi wa Al-Turki, Arab Institute for Studies and Publishing, Beirut.

[19] Mika N., (2002). The Zafar Nama: Book of conquest of Sultan Husayn Mirza, in: Hourihane, C. (ed.) Sights and Interpretations, Princeton Univ., USA, pp: 211-228

[20] Ibn Manzoor, G., (1997). Lisan Alarab (Arab Tung), Vol 2, Dar Sadir, Beirut.

[21] Matloub, A., (1995). Mu'jam al malabis fi lisan Al-Arab, $1^{\text {st }}$ ed., Lebanon Library, Beirut.

[22] Abdel Jawad, R., (2002). Al-mu'jam Al-arabi li asmaa al-malabis, $1^{\text {st }}$ ed., Dar Alafak Alarabia, Cairo.

[23] Dozy, R., (1971). Al-mu'jam al mofassal bi-asmaa al-malabis, Al-Horia Printing House, Baghdad.

[24] Nasrallah, S. \& Tahoun, Z., (1996). Tarikh al-aziaa, Alam Alkotob, Cairo.

[25] Ady, S., (1980). Al-alfaz al-farsia almo'rabaa, Catholic Jesuites Publishing House, Lebanon.

[26] Roxburgh, D., (2009), Ruy Gonza'lez De clavijo's narrative of courtly life and ceremony in Timur's Samarqand, in: Brummet, P. (ed.) The 'book' of Travels: Genre, Ethnology, and Pilgrimage, 1250-1700, Brill, Leiden, pp: 113-153.

[27] O'kane, B., (2009). Reconciliation or estrangement? Colophon and paintings in the Tiem Zafarnāma and some other controversial manuscripts, Muqarnas, Vol. 26, pp: 205-227 